\author{
옥수수 가공방법이 In sacco 전분 및 단백질 분해율에 \\ 미치는 영향 \\ 손근남*김용국*이수기*김현섭** \\ 충남대학교 동물자원학부*, 농촌진흥청 축산기술연구소**
}

\title{
The Effects of Processing Methods of Corn on In sacco Starch and Protein Degradability in the Rumen
}

\author{
K. N. Son*, Y. K. Kim*, S. K. Lee* and H. S. Kim** \\ Devision of Animal Science \& Resources, Chungnam National University*, \\ National Livestock Research Institute**
}

\begin{abstract}
The objective of this study was to examine the effects of processing methods of corn grains on protein and starch degradability in the rumen by three ruminally cannulated dry Holstein cows. The corns for these experiments were untreated; whole corn L(density; $660 \mathrm{~g} / \ell$ ), whole corn $\mathrm{H}$ (density; 740 $\mathrm{g} / \ell$ ), and treated by four different types: Ground corn, $3.8 \mathrm{~mm}, 2.8 \mathrm{~mm}$, and $1.5 \mathrm{~mm}$ flaked corn. The results obtained were summarized as follows :

For $48 \mathrm{hrs}$, the protein degradabilities were high in order, ground corn, $1.5 \mathrm{~mm}, 2.8 \mathrm{~mm}$, and 3.8 $\mathrm{mm}$ flaked corn(82.6, 76.5, 64.5, and 33.9\%, respectively). Flaked corn grains were degraded lower than ground corn. However, as increasing the processing degree of flaking, the protein degradabilities, from 4 hrs to $48 \mathrm{hrs}$, were increased. The starch degradabilities on $48 \mathrm{hrs}$ were higher in 1.5 and $2.8 \mathrm{~mm}$ flaked corns, ground corn, $3.8 \mathrm{~mm}$ flaked corn(99.1, 91.5, 89.5, and $68.9 \%$, respectively) than whole corn $\mathrm{L}(32.0 \%)$ and whole corn $\mathrm{H}(20.5 \%)(\mathrm{P}<0.05)$. By increasing the processing degree of flaking, the protein degradabilty between $2.8 \mathrm{~mm}$ and $3.8 \mathrm{~mm}$ was increased significantly from $68.9 \%$ to $91.5 \%$, however, that of $1.5 \mathrm{~mm}$ flaked corn, processed thinner, tended to be increased slightly, but was not significantly different. From $12 \mathrm{hrs}$ to $24 \mathrm{hrs,}$, whole corn L was degraded little more than whole corn $\mathrm{H}$ in starch, was not significantly different. However, after $48 \mathrm{hr}$ incubation in the rumen, whole corn $\mathrm{L}$ was degraded more $50 \%$ than whole corn $\mathrm{H}(\mathrm{P}<0.05)$. The value of degradation parameter "a" of protein was lower in all flaked corns than in ground corn. In contrast, the value of degradation parameter "a" of starch was significantly higher in all flaked corns than in ground $\operatorname{corn}(\mathrm{P}<0.05)$. It seemed that by flaking the corn grains, starch particles were gelatinized, and then, starch was degraded more rapidly, while protein was degraded more slowly. Referring to these kinds of physical characteristics of grain sources in ruminal degradabilities, it is possible to synchronize the fermentation of nitrogen and carbohydrate sources, in formulating the cattle diets.

(Key words : In sacco starch and protein degradability, Processing methods, Corn grains)
\end{abstract}

Corresponding author : Y. K. Kim, Devision of Animal Sience \& Resources, College of Agriculture \& Life Sience, Chungnam National University, 220 Kung-Dong, Yusung-Ku, Daejon, 305-764, Republic of Korea. E-mail: yongkook@cnu.ac.kr Tel: 042-821-5787 Fax: 042-823-2766. 


\section{I. 서 론}

2001년 현재 국내 배합사료 생산 원료 중에 서 수입 원료가 $74.6 \%$ 로서 수입 의존도가 높으 며, 곡류 수입량은 7,916천 톤으로 전체 수입 원료의 $71.5 \%$ 에 달하고 있다(한국축산연감, 2002). 그리하여 곡류의 이용효율을 증진시키는 가공방법의 연구는 매우 중요하며, 한편으로는 가공 정도에 있어서의 적정점을 찾고 과도한 가공처리에 드는 제조비용의 낭비를 최소화할 필요가 있다.

국내 배합사료업계에서 축우사료 제조시에 일반적으로 사용하고 있는 옥수수 가공형태는 분쇄 및 flaking이며, 홀스타인 숫소 비육용으 로는 볏짚 등 조사료를 급여하지 않고 통 옥수 수 형태를 사용하고 있다.

Alio 등(2000), Theurer 등(1999), Lozano 등 (2000) 및 Brown 등(2000)은 옥수수 flake의 가 공 정도를 용적중(density, $\mathrm{g} / \ell$ )에 따라 분류하 여 건물 섭취량, 일당 증체량, 소화율 및 질소 의 재순환(recycling) 등을 연구한 결과, 비육우 용 사료에서는 용적중이 큰 flake $(437 \mathrm{~g} / \ell)$ 보다 는 적은 flake $(283 \mathrm{~g} / \ell)$ 가 흡수이용율이 높다고 하였다. Flake의 가공효과에 영향을 미치는 주 요 요인은 습열처리(steaming)시의 온도, 시간 및 압력이며(Fredrick 등, 1973; Zinn, 1990a, 1990b), 동일한 시설이라도 단열성, 열 재환원 성 등에 따라 영향을 받는다. 이 외에도 대상 원료 자체의 물리화학적 특성에 따라서 가공효 과는 영향을 받으며, flaking 롤러의 두께와 간 극도 영향을 미친다. 박편 처리된 flake의 두께, 박편밀도, 전분의 젤라틴화는 위의 여러 요인 들의 복합적인 작용을 받는다고 사료된다.

Philippeau 등(1999)은 옥수수 품종에 따른 소 화율을 연구한 결과 반추위내 전분의 소화율이 dent종이 flint종보다 높다고 보고하였다. 그러 나 옥수수의 수입시에 품종이나 생산지는 명시 되지 않고 거래되고 있으며, 품질의 보증하는 대표적인 방법으로 용적중이 이용되고 있다.

따라서, 본 연구에서는 용적중이 다른 두 종 류의 통 옥수수를 공시하였으며, 전분의 젤라 틴화의 정도와 두께에 따른 3 종의 옥수수 flake
및 분쇄 옥수수를 시험재료로 사용하여 반추위 내에서의 전분 및 단백질의 분해율에 미치는 영향을 배양 시간대별로 측정함으로써 반추가 축용 사료 배합시 에너지원과 단백질원의 반추 위 발효 동기화를 고려하는 기초 자료로 활용 하고자 수행하였다.

\section{П. 재료 및 방법}

\section{1. 공시축 및 사양관리}

반추위에 누관(cannulae)이 장착된 체중 620 $\mathrm{kg}$ 정도의 Holtein 종 건유우 3 두를 공시하였으 며, 혼합 목건초와 물을 자유채식토록 하였다.

\section{2. 시험기간 및 장소}

2002년 10월 11일부터 10 월 30 일까지 20일 간 농촌진흥청 축산기술연구소에서 실시하였 다.

\section{3. 공시 사료}

통 옥수수 2 종(density $660 \mathrm{~g} / \ell$ 와 $740 \mathrm{~g} / \ell$ ), 분쇄 옥수수 및 flaking한 옥수수 3종(두께 3.8 $\mathrm{mm}, 2.8 \mathrm{~mm}$ 및 $1.5 \mathrm{~mm}$ ) 등 총 6 종의 옥수수를 공시재료로 사용하였다. 국내에서 축우용 배합 사료 제조시에 통상적으로 많이 사용하고 있는 옥수수 가공형태로서 이들 6종의 시료를 채택 하였다.

\section{(1) 공시 사료의 물리적 특성}

공시사료의 물리적 특성은 Table 1에서 보는 바와 같으며, 통 옥수수는 density가 $660 \mathrm{~g} / \ell$ 인 낮은 것 $($ whole corn $\mathrm{L}$ )과 $740 \mathrm{~g} / \ell$ 인 높은 것 (whole corn H)으로 구분하였다. 물리적 특성을 측정하는 방법은 국내 배합사료 회사에서 통상 적으로 사용하는 방법으로 다음과 같다.

1) 밀도(용적중, density, $\mathrm{g} / \ell$ )

내경 $122 \mathrm{~mm}$ 의 $1 \ell$ 용 원통형 용기를 사용 하여 상단 $10 \mathrm{~cm}$ 위에서 시료를 자유 낙하시켜 
Table 1. Physical properties of experimental corns

\begin{tabular}{lccc}
\hline Treatments & $\begin{array}{l}\text { Density } \\
(\mathrm{g} / \ell)\end{array}$ & $\begin{array}{c}\text { Thickness } \\
(\mathrm{mm})\end{array}$ & \multicolumn{1}{c}{ Particle size } \\
\hline \hline Whole corn L & 660 & 4.5 & $89.3 \%$ on $6.7 \mathrm{~mm} \mathrm{screen}$ \\
Whole corn H & 740 & 4.4 & $82.9 \%$ on $6.7 \mathrm{~mm} \mathrm{screen}$ \\
Ground corn & 580 & - & $54.9 \%$ in $1.18 \sim 3.35 \mathrm{~mm}$ \\
Flaked, $3.8 \mathrm{~mm}$ & 540 & 3.8 & - \\
Flaked, $2.8 \mathrm{~mm}$ & 480 & 2.8 & - \\
Flaked, $1.5 \mathrm{~mm}$ & 290 & 1.5 & - \\
\hline
\end{tabular}

중량을 $\mathrm{g}$ 단위로 3 회 측정하여, 평균값을 $10 \mathrm{~g}$ 단위로 반올림하였다.

\section{2) 두께(thickness, mm)}

무작위로 24 개의 샘플을 선정, 반듯이 눕혀 진 종실의 가장 두꺼운 부분의 두께를 vernier calipers로 측정하여, 최소 및 최대치 각각 2 개 를 제외한 나머지 20 개의 평균치를 $\mathrm{mm}$ 단위, 소숫점 2자리에서 반올림하였다.

\section{3) 입자도(particle size)}

분쇄 옥수수의 입자도는 screen size가 각각 $0.35,0.60,1.18,170,2.36$ 및 $3.35 \mathrm{~mm}$ 의 표준체 를 사용하여 5 분간 진탕 후, 각 screen에 남아
있는 시료량을 7 회 반복하여 평균값을 구하였 다. 통 옥수수는 sieve shaker에 5 분간 진탕 후, $6.7 \mathrm{~mm}$ screen에 남아 있는 시료량을 3 회 반복 하여 평균치를 구하였다.

(2) 공시 사료의 일반성분

공시 사료의 일반성분은 Table 2에서 보는 바와 같으며, 전분의 젤라틴화는 통옥수수 및 분쇄 옥수수가 $25.1 \sim 26.6 \%$ 이었고, $3.8 \mathrm{~mm}$ 와 $2.8 \mathrm{~mm}$ flake는 각각 $40.4,39.2 \%$ 이었으며, $1.5 \mathrm{~mm}$ flake는 $66.4 \%$ 로 가장 높았다. 공시 사 료와 배양 후의 잔존 시료의 일반성분 함량은 AOAC법(1990)에 의하여 분석하였다.

Table 2. Chemical composition of experimental corns

\begin{tabular}{lccccccc}
\hline \multirow{2}{*}{ Treatments } & \multicolumn{7}{c}{ Chemical composition } \\
\cline { 2 - 7 } & DM & CP & EE & CA & NDF & Starch & Gel. s. \\
\hline as fed & $\ldots \ldots \ldots \ldots \ldots \ldots \ldots \ldots$. & $\%$ of DM & $\ldots \ldots \ldots \ldots \ldots \ldots \ldots \ldots$ & $\%$ * $^{*}$ \\
Whole corn L & 87.0 & 8.31 & 3.56 & 1.33 & 11.5 & 58.6 & 26.0 \\
Whole corn H & 85.9 & 7.94 & 3.55 & 1.20 & 11.9 & 60.9 & 25.1 \\
Ground corn & 86.9 & 8.02 & 3.25 & 1.04 & 11.9 & 52.0 & 26.6 \\
Flaked, 3.8 mm & 85.8 & 8.29 & 3.45 & 1.15 & 15.7 & 59.3 & 40.4 \\
Flaked, 2.8 mm & 86.7 & 8.07 & 3.82 & 1.23 & 12.4 & 52.9 & 39.2 \\
Flaked, $1.5 \mathrm{~mm}$ & 87.0 & 7.63 & 2.35 & 0.86 & 14.5 & 53.5 & 66.4 \\
\hline
\end{tabular}

DM; Dry Matter, CP; Crude Protein, EE; Ether Extract, CA; Crude Ash, NDF; Neutral Detergent Fiber, Gel. s.; Gelatinized starch. \%*: = Gelatinized starch $\div$ total starch $\times 100$. 
(3) 공시사료의 가공방법

분쇄 옥수수는 hammer mill를 사용하였으며, screen을 통과시키지 않았으며 분쇄 입자도는 Table 1 과 같다. Flake는 $110^{\circ} \mathrm{C}$ 에서 15 분간 steaming한 후 roller의 간극를 달리하여 두께를 조절하였다.

\section{4. 시험 설계}

옥수수 가공방법에 따른 6처리로 시험을 수 행하였다. 반추위 배양시간은 $0,2,4,8,12$, 24 , 및 48 시간으로 각각 3 회 반복 처리하였다. Nylon bags(Swiss screen P/L Co. Ltd, NYTAL $25 \mathrm{~T}$, pore size; $45 \mu \mathrm{m}$ )은 $5 \mathrm{~cm} \times 10 \mathrm{~cm}$ 크기로 제작하였다.

\section{5. 시험 방법 및 조사 항목}

\section{(1) 시험 방법}

약 $5 \mathrm{~g}$ 의 시료를 칭량하여 nylon bag에 넣고, 나이론 끈(낚시줄용)으로 $\mathrm{bag}$ 의 끝에서 $2.5 \mathrm{~cm}$ 지점을 묶은 다음, 큰 그물망 (크기: 가로 $15 \mathrm{~cm}$ $\times$ 세로 $25 \mathrm{~cm}$ )에 다시 넣어 따뜻한 물에 15 분 간 수침하였다. 캐뉼라의 뚜껑을 열고 반추위 ventral sac 쪽으로 nylon bag이 든 그물망을 넣 고, 캐뉼라 뚜껑을 닫았다. 그 후 배양시간대별 로 캐뉼라 뚜껑을 열고 회수한 nylon bag을 즉 시 얼음물에 침지하여 미생물의 생육을 억제하 였다. 단, 0시간대는 nylon bag 시료를 반추위 캐뉼라에 넣지 않았다. 회수한 nylon bag을 맑 은 물이 나올 때까지 30 분 동안 세척하였다. 이것을 $70^{\circ} \mathrm{C}$ 건조기에서 48 시간 건조한 후 무 게를 칭량하였다(Van Keuren과 Heineman, 1962).

\section{(2) 조사 항목}

1) 영양소 분해율 $(\%)=$ 배양전 영양소 무게배양후 영양소 무게

배양전 영양소 무게 $\times 100$
2) 분해상수

반추위 소실율을 기초로 하여 Marquardt (1963)법을 응용한 SAS(1988)의 비선형회귀 (NLIN) program에 의해 다음의 분해도 공식(0 rskov와 McDonald, 1979)으로 a, b, c 값을 산 출하였다.

$$
P=a+b\left(1-e^{-c t}\right)
$$

$\mathrm{P}$ : 시간 " $\mathrm{t}$ " 경과시 반추위내 영양소의 분해 율(\%)

$\mathrm{a}$ : 시간 "o"시간대의 영양소의 분해율 $(\%)$, 즉 빠르게 분해되는 부분을 의미,

$\mathrm{b}$ : 주어진 시간에 있어서 분해될 수 있는 영양소의 잠재적 분해율(\%)

$\mathrm{c}$ : "b"의 시간당 분해상수

$\mathrm{t}$ : 반추위내 배양시간

$\mathrm{e}$ : 자연 대수의 밑

(3) 유효 분해도 (Effective ruminal degradability, ED or ERD)

유효 분해도는 사료의 반추위내 통과속도를 급여사료의 종류에 따라 $0.02,0.04$ 및 $0.06 \mathrm{~h}^{-1}$ 을 적용하여 다음과 같은 공식에 의해 추정하 였다(NRC. 1984, Ørskov와 McDonald, 1979). $\operatorname{ERD}(\%)=\mathrm{a}+\mathrm{b}[\mathrm{c} /(\mathrm{c}+\mathrm{k})]$

여기서, $\mathrm{ERD}$ 는 반추위내 유효 분해도이며, $\mathrm{k}$ 는 사료의 반추위내 통과속도(passage rate)이고, $\mathrm{a}, \mathrm{b}, \mathrm{c}$ 는 분해상수에서와 동일하다.

\section{6. 통계처리}

SAS(Statistical analysis system) 통계 프로그 램을 이용하여 분산분석을 실시하고, 평균간의 차이는 DMRT(Duncan Multiple Range Test)로 $5 \%$ 수준에서 유의성을 검정하였다(Duncan, 1955). 


\section{III. 결과 및 고찰}

1. 옥수수 가공형태에 따른 반추위 배양시간 별 전분 분해율, 잔량의 전분 함량, 전분 분해상수 및 유효 전분 분해도

\section{(1) 전분 분해율}

반추위 배양시간별 전분 분해율은 Table 3 에 서 보는 바와 같으며, 48 시간대에서의 전분 분 해율은 $1.5 \mathrm{~mm}$ 및 $2.8 \mathrm{~mm}$ flake가 가장 높았고 (98.1 및 91.5\%), whole corn $\mathrm{H}(20.5 \%)$ 가 가장 낮았다 $(\mathrm{P}<0.05)$. Callison 등(2001)은 옥수수 flake 가공시, 전분 소화율을 최대화하기 위한 박편밀도는 $530 \mathrm{~g} / \ell$ 이하이어야 한다고 보고하 였는데, 본 시험의 결과는 $540 \mathrm{~g} / \ell(3.8 \mathrm{~mm}$ flake)에서 $480 \mathrm{~g} / \ell$ (2.8mm flake)로 density가 낮 아졌을 때, 전분 소화율은 $68.9 \%$ 에서 $91.5 \%$ 로 서 유의하게 높아졌으며, $290 \mathrm{~g} / \ell(2.8 \mathrm{~mm}$ flake) 로 더욱 낮아졌을 때에는 $98.1 \%$ 로 완만한 증가 를 보였으나, 유의적인 증가는 아니었다 $(\mathrm{P}<$ 0.05). Phillippeau 등(1999)은 옥수수 품종(dent type과 flint type)에 따른 반추위내 전분 소화율 을 측정한 결과, dent종이 flint종보다 $50 \%$ 이상
높았다고 보고하였는 바, 본 시험의 결과는 2 24시간에서는 density가 다른 통 옥수수간에 유의적인 차이가 나타나지 않았으나, 48 시간대 에서는 density가 낮은 통 옥수수 $(32.0 \%)$ 가 높 은 것 $(20.5 \%)$ 보다 전분 분해율이 $50 \%$ 가량 더 높았다. 이는 density가 낮으면 단위 중량당 부 피가 크므로 반추위 미생물이 옥수수 종실 내 부로 침투하기가 보다 용이하였기 때문으로 생 각된다. 반추 작용을 위한 목적으로 통 옥수수 를 사용할 시는 이와 같은 분해특성을 고려하 여야 하겠다.

\section{(2) 잔량의 전분 분해율}

반추위 내에서 배양시간대별로 nylon bag에 남아 있는 건물 중의 전분 함량을 측정한 결과 는 Table 4와 같다. $1.5 \mathrm{~mm}$ flake는 8 시간대 (57.1\%)부터, $\quad 2.8 \mathrm{~mm}$ 는 $\quad 12$ 시간대(59.9\%)부터, $3.8 \mathrm{~mm}$ flake 및 분쇄 옥수수는 24시간대(54.8 및 $58.5 \%$ )부터 낮아지는 경향을 나타내었다. 48 시간대에서의 잔량의 전분 함량은 통 옥수수 $\mathrm{H}$ 및 $\mathrm{L}(67.2$ 및 $66.4 \%)$ 이 가장 높았고, $3.8 \mathrm{~mm}$ flake, 분쇄 옥수수, $2.8 \mathrm{~mm}$ flake, $1.5 \mathrm{~mm}$ flake의 순으로 유의하게 낮아졌다 $(\mathrm{P}<0.05)$. 즉, flake의

Table 3. Starch degradabilities of untreated and treated corns by incubation time in the rumen of Holstein cows

\begin{tabular}{lcccccc}
\hline \multirow{2}{*}{ Treatments } & \multicolumn{5}{c}{ Incubation time in the rumen(hrs) } \\
\cline { 2 - 7 } & 0 & 2 & 4 & 8 & 12 & 24 \\
\hline \hline \\
\hline
\end{tabular}


가공정도가 높아질수록 48 시간대에서 잔량의 전분 함량은 낮아졌다. Theurer 등(1999)은 flake density를 감소시키면, 반추위 내에서의 전분 소화율은 증진되고 소장내에서 소화되는 부분은 감소되나, 총 장관(total tract)내에서의 전분 소화율은 증가되어 비육우의 경우에 사료 효율이 증진된다고 하였다. 이는 증기박편에 의하여 표면적의 증가로 반추위내에서 미생물 의 침투가 용이할 뿐 아니라, a-전분의 양이 증 가하고, 전분 주위의 단백질막이 파괴되었기 때문으로 사료된다(Owens 등, 1986).
(3) 전분 분해상수

전분 분해 상수는 Table 5에서 보는 바와 같 이 물에 녹는 수용성 부분, 즉 “a" 값은 $1.5 \mathrm{~mm}$ flake가 $17.4 \%$ 로 가장 높았고, 분쇄 옥수수가 $9.1 \%$ 로 가장 낮았다 $(\mathrm{P}<0.05)$. 반추위에서 미생 물에 의해 분해되는 부분인 "b"값은 13.6 $74.4 \%$ 로서 처리간에 많은 차이가 있었다. 1.5 $\mathrm{mm}$ flake가 $74.4 \%$ 로서 가장 높았으며, 다음으 로 분쇄 옥수수, $2.8 \mathrm{~mm}$ 및 $3.8 \mathrm{~m}$ flake가 각각 $67.4,66.1$ 및 $58.1 \%$ 이었으며, 통 옥수수 $\mathrm{L}$ 및 $\mathrm{H}(27.7$ 및 $13.6 \%)$ 는 이들보다 유의하게 낮았다.

Table 4. Starch contents in residues of untreated and treated corns by incubation time in the rumen

\begin{tabular}{|c|c|c|c|c|c|c|c|}
\hline \multirow{2}{*}{ Treatments } & \multicolumn{7}{|c|}{ Incubation time in the rumen(hrs) } \\
\hline & 0 & 2 & 4 & 8 & 12 & 24 & 48 \\
\hline & 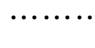 & & & $\%$ & & & \\
\hline Whole corn $\mathrm{L}$ & $62.4^{\mathrm{c}}$ & $64.2^{\mathrm{ab}}$ & $65.1^{\mathrm{bc}}$ & $63.6^{\mathrm{b}}$ & $63.2^{\mathrm{b}}$ & $65.2^{\mathrm{b}}$ & $66.4^{\mathrm{a}}$ \\
\hline Whole corn $\mathrm{H}$ & $61.7^{\mathrm{c}}$ & $63.5^{\mathrm{abc}}$ & $65.0^{\mathrm{b}}$ & $64.6^{\mathrm{a}}$ & $65.9^{\mathrm{a}}$ & $66.2^{\mathrm{a}}$ & $67.2^{\mathrm{a}}$ \\
\hline Ground corn & $64.5^{\mathrm{ab}}$ & $64.8^{\mathrm{a}}$ & $66.5^{\mathrm{a}}$ & $58.2^{\mathrm{e}}$ & $61.1^{\mathrm{c}}$ & $58.5^{\mathrm{c}}$ & $52.6^{\mathrm{c}}$ \\
\hline Flaked, $3.8 \mathrm{~mm}$ & $64.0^{\mathrm{b}}$ & $63.2^{\mathrm{bc}}$ & $64.6^{\mathrm{bc}}$ & $62.1^{\mathrm{d}}$ & $60.5^{\mathrm{cd}}$ & $54.8^{\mathrm{d}}$ & $56.2^{\mathrm{b}}$ \\
\hline Flaked, $2.8 \mathrm{~mm}$ & $61.7^{\mathrm{c}}$ & $63.2^{\mathrm{bc}}$ & $63.8^{\mathrm{c}}$ & $62.8^{\mathrm{c}}$ & $59.9^{\mathrm{d}}$ & $54.8^{\mathrm{d}}$ & $40.1^{\mathrm{d}}$ \\
\hline Flaked, $1.5 \mathrm{~mm}$ & $65.2^{\mathrm{a}}$ & $62.6^{\mathrm{c}}$ & $62.4^{\mathrm{d}}$ & $57.1^{\mathrm{f}}$ & $47.6^{\mathrm{e}}$ & $25.4^{\mathrm{e}}$ & $21.4^{\mathrm{e}}$ \\
\hline SEM & 0.36 & 0.26 & 0.32 & 0.68 & 1.40 & 3.30 & 3.87 \\
\hline
\end{tabular}

Table 5. Starch degradation parameters of untreated and treated corns by incubation time in the rumen

\begin{tabular}{lccc}
\hline Treatments & \multicolumn{3}{c}{ Degradation parameters } \\
\cline { 2 - 4 } & $\mathrm{a}(\%)$ & $\mathrm{b}(\%)$ & $\mathrm{c}$ \\
\hline \hline Whole corn L & $13.3^{\mathrm{c}}$ & $27.7^{\mathrm{c}}$ & $0.021^{\mathrm{d}}$ \\
Whole corn H & $17.1^{\mathrm{ab}}$ & $13.6^{\mathrm{d}}$ & $0.009^{\mathrm{d}}$ \\
Ground corn & $9.1^{\mathrm{d}}$ & $67.4^{\mathrm{ab}}$ & $0.067^{\mathrm{b}}$ \\
Flaked, $3.8 \mathrm{~mm}$ & $14.9^{\mathrm{bc}}$ & $58.1^{\mathrm{b}}$ & $0.048^{\mathrm{c}}$ \\
Flaked, $2.8 \mathrm{~mm}$ & $10.1^{\mathrm{d}}$ & $66.1^{\mathrm{ab}}$ & $0.066^{\mathrm{b}}$ \\
Flaked, $1.5 \mathrm{~mm}$ & $17.4^{\mathrm{a}}$ & $74.4^{\mathrm{a}}$ & $0.106^{\mathrm{a}}$ \\
\hline SEM & 0.81 & 5.59 & 0.0079 \\
\hline
\end{tabular}

a,b,c,d Means in the same column with different superscripts are significantly $\operatorname{different}(\mathrm{P}<0.05)$. 
Density가 다른 통 옥수수간에 "b"값은 유의적 인 차이가 있었으며 $(\mathrm{P}<0.05)$, density가 낮은 것 (27.7\%)이 높은 것(13.6\%)보다 2배 정도 높았 다. 반추위내 분해율에 결정적인 영향을 미치 는 매우 중요한 상수인 “c”값(즉, 'b' 부분이 시 간당 반추위를 통과하는 비율)은 $1.5 \mathrm{~mm}$ flake 가 0.106 으로 가장 높았으며, 그 다음이 분쇄 옥수수 및 $3.8 \mathrm{~mm}$ flake(0.067 및 0.066)이었다. 통 옥수수 $\mathrm{L}$ 및 $\mathrm{H}(0.021$ 및 0.009)는 가공 처 리시에 비하여 유의하게 낮았으며 $(\mathrm{P}<0.05)$, density가 낮은 것이 높은 것보다 “c"값이 2 배 이상 높게 나타났으며, 그만큼 반추위내 정체 시간이 짧을 것으로 생각되었다. Flake 가공정 도에 따른 "a"값은 $1.5 \mathrm{~mm}$ flake( $17.4 \%$ )가 가장 높았는데, 이는 반추위내 미생물에 의해 발효 되지 못하고 손실되는 것을 의미하므로, flake 의 가공정도를 과다하게 증가시키는 것은 제조 가공비용의 증가와 함께 이중의 손실을 가져올 수 있다고 사료된다.

(4) 유효 전분 분해도

각 처리별 반추위내 시간당 통과속도 $\mathrm{k}=0.02$, $0.04,0.06$ 를 적용한 반추위 내 유효 전분 분해 도는 Table 6 에서 보는 바와 같다. $1.5 \mathrm{~mm}$ 의 얇
은 flake가 $65.3 \sim 53.7 \%$ 로서 가장 높았으며, 다 음은 $2.8 \mathrm{~mm}$ flake 및 분쇄 옥수수가 39.3 $54.0 \%$ 로서 유사한 결과를 나타내었으며, 3.8 $\mathrm{mm}$ 의 두꺼운 flake(34.0\%)는 이들보다 유의하 게 낮았다 $(\mathrm{P}<0.05)$. 즉, flake의 가공정도를 증 가시킬수록 유효 전분 분해도는 높아졌다. 통 옥수수 L 및 $\mathrm{H}(14.6 \sim 20.9 \%)$ 는 가공처리시보다 낮았다. Brown 등(2000)은 비육우의 경우 최적 의 효율은 flake density가 $360 \mathrm{~g} / \ell \sim 260 \mathrm{~g} / \ell$ 범 위라고 하였고, Callison 등(2001)은 전분 소화 율을 최대화하기 위해서는 $530 \mathrm{~g} / \ell$ 미만이어야 한다고 하였는바, 본 시험의 결과도 이들과 유사한 경향을 보여 주었다.

2. 옥수수 가공형태에 따른 반추위 배양시간 별 단백질 분해율, 잔량의 단백질 함량, 단백질 분해상수 및 유효 단백질 분해도

\section{(1) 단백질 분해율}

Table 7에서 보는 바와 같이 반추위내 배양 시간이 경과함에 따라 단백질 분해율은 증가하 는 경향을 보여 주었다. 12 시간대까지의 각 시 간대별 가공형태에 따른 단백질 분해율은 분쇄 옥수수(21.5 36.1\%)가 가장 높았고, flake 처리

Table 6. Effective starch degradabilities of untreated and treated corns by incubation time in the rumen

\begin{tabular}{lccc}
\hline Treatments & \multicolumn{2}{c}{ ERD*(\%) } \\
\cline { 2 - 4 } & $\mathrm{k}=0.02$ & $\mathrm{k}=0.04$ & $\mathrm{k}=0.06$ \\
\hline \hline Whole corn L & $20.9^{\mathrm{d}}$ & $18.5^{\mathrm{d}}$ & $17.2^{\mathrm{d}}$ \\
Whole corn H & $14.6^{\mathrm{e}}$ & $15.4^{\mathrm{d}}$ & $15.8^{\mathrm{d}}$ \\
Ground corn & $54.0^{\mathrm{b}}$ & $46.7^{\mathrm{b}}$ & $39.9^{\mathrm{b}}$ \\
Flaked, $3.8 \mathrm{~mm}$ & $45.3^{\mathrm{c}}$ & $38.4^{\mathrm{c}}$ & $34.0^{\mathrm{c}}$ \\
Flaked, $2.8 \mathrm{~mm}$ & $53.6^{\mathrm{b}}$ & $44.9^{\mathrm{b}}$ & $39.3^{\mathrm{b}}$ \\
Flaked, $1.5 \mathrm{~mm}$ & $65.3^{\mathrm{a}}$ & $58.7^{\mathrm{a}}$ & $53.7^{\mathrm{a}}$ \\
\hline SEM & 4.49 & 3.75 & 3.24 \\
\hline
\end{tabular}

ERD*: Effective rumen degradability calculated with the equation of $E R D=a+b[c /(c+k)]$, where $k$ is the rate of passage set at $0.02,0.04$ and 0.06 .

a,b,c,de Means in the same column with different superscripts are significantly $\operatorname{different}(\mathrm{P}<0.05)$. 
Table 7. Protein degradabilities of untreated and treated corns by incubation time in the rumen

\begin{tabular}{|c|c|c|c|c|c|c|c|}
\hline \multirow{2}{*}{ Treatments } & \multicolumn{7}{|c|}{ Incubation time in the rumen(hrs) } \\
\hline & 0 & 2 & 4 & 8 & 12 & 24 & 48 \\
\hline & $\cdot$ & & 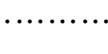 & $\%$ & $\cdots \cdots \cdot$ & - & $\cdots$ \\
\hline Whole corn $\mathrm{L}$ & $16.1^{\mathrm{b}}$ & $14.3^{\mathrm{b}}$ & $16.2^{\mathrm{bc}}$ & $15.6^{\mathrm{b}}$ & $17.0^{\mathrm{b}}$ & $25.8^{\mathrm{b}}$ & $36.3^{\mathrm{c}}$ \\
\hline Whole corn $\mathrm{H}$ & $14.5^{\mathrm{c}}$ & $14.5^{\mathrm{b}}$ & $10.3^{d}$ & $12.0^{\mathrm{b}}$ & $19.8^{\mathrm{b}}$ & $19.4^{\mathrm{bc}}$ & $26.2^{\mathrm{c}}$ \\
\hline Ground corn & $21.5^{\mathrm{a}}$ & $21.4^{\mathrm{a}}$ & $25.1^{\mathrm{a}}$ & $27.5^{\mathrm{a}}$ & $36.1^{\mathrm{a}}$ & $52.6^{\mathrm{a}}$ & $82.6^{\mathrm{a}}$ \\
\hline Flaked, $3.8 \mathrm{~mm}$ & $7.2^{\mathrm{e}}$ & $8.9^{\mathrm{c}}$ & $10.7^{\mathrm{cd}}$ & $7.4^{\mathrm{bc}}$ & $18.7^{\mathrm{b}}$ & $25.4^{\mathrm{b}}$ & $33.9^{c}$ \\
\hline Flaked, $2.8 \mathrm{~mm}$ & $5.1^{f}$ & $8.0^{\mathrm{c}}$ & $8.9^{\mathrm{d}}$ & $14.5^{\mathrm{b}}$ & $23.1^{\mathrm{b}}$ & $25.9^{\mathrm{b}}$ & $64.5^{\mathrm{b}}$ \\
\hline Flaked, $1.5 \mathrm{~mm}$ & $10.5^{\mathrm{d}}$ & $14.4^{\mathrm{b}}$ & $17.1^{\mathrm{b}}$ & $15.4^{\mathrm{b}}$ & $14.6^{\mathrm{b}}$ & $45.6^{\mathrm{a}}$ & $76.5^{\mathrm{ab}}$ \\
\hline SEM & 1.35 & 1.22 & 1.48 & 1.76 & 2.05 & 3.22 & 5.65 \\
\hline
\end{tabular}

a,b,c,d,e,f Means in the same column with different superscripts are significantly different $(\mathrm{P}<0.05)$.

한 옥수수는 3종 모두(5.1 23.1\%) 이보다 낮 았다 $(\mathrm{P}<0.05)$. 이러한 결과는 Fiems 등(1990) 및 Focant 등(1990)이 곡류를 고온스팀으로 flaking 처리하면 전분의 젤라틴화는 증가하지만 반추 위 내의 단백질 소화율은 낮아진다고 한 보고 와 일치하며, 그 이유는 첫째, 고온으로 가공처 리를 하면 단백질이 반추위 내에서 분해가 잘 이루어지지 않는 변성 단백질화 된다는 것과 둘째, 젤라틴화 된 전분이 반추위 내에서의 단 백질 분해를 감소시켜, 십이지장내의 단백질 유입량이 늘어나기 때문이라고 하였다. 또한 flake 두께에 따른 단백질 분해율은 $3.8 \mathrm{~mm}$, $2.8 \mathrm{~mm}$ 및 $1.5 \mathrm{~mm}$ 가 48 시간대에서 각각 33.9 , 64.5 및 $76.5 \%$ 로 얇게 가공할수록 증가되는 경 향이었다. 또한 Xiong 등(1991)이 수수의 flaking density에 따른 in vitro상의 젤라틴화 및 단백질 분해율을 시험한 결과, 밀도가 감소함 에 따라 젤라틴화는 증가되고, 단백질 분해율 은 감소한다고 한 보고와는 젤라틴화의 증가 경향은 일치하지만 단백질 분해율의 경향은 상 반되는 결과를 나타내었다.

\section{(2) 잔량의 단백질 함량}

Table 8은 배양시간별로 nylon bag에 남아있 는 건물 중의 단백질 함량을 측정한 결과이다. 배양시간이 경과함에 따라 통 옥수수의 경우는 거의 변화가 없었으며, 분쇄 옥수수 및 $3.8 \mathrm{~mm}$ flake는 완만한 증가를 보인 반면에 $2.8 \mathrm{~mm}$ flake는 48시간대에서, $1.5 \mathrm{~mm}$ flake는 24시간대 부터 급격히 증가되었다. 2 48시간대에서 flake 처리한 옥수수들의 잔량의 단백질 함량은 두께가 얇아질수록 유의하게 증가하였으며, 잔 량의 단백질 함량만으로 본다면 앞에서 언급한 Xiong 등(1991)의 보고와 같은 경향으로 젤라 틴화의 증가에 따른 소화되지 않은 단백질의 양이 증가된 것을 나타내고 있다. 고능력우의 사료배합시 반추위 내에서 분해되지 않는 단백 질(RUP)의 함량을 고려하여야 하는데(NRC, 2001), 단백질의 이용효율 면에서 본다면 flaking 처리가 보다 효과적(Volden, 1999)이라고 보고하였는데, 이는 flaking 처리에 의해 단백 질이 변성되면 소장에서도 소화되지 않을 가능 성이 있다고 사료된다. 
Table 8. Protein contents in residues of untreated and treated corns by incubation time in the rumen

\begin{tabular}{|c|c|c|c|c|c|c|c|}
\hline \multirow{2}{*}{ Treatments } & \multicolumn{7}{|c|}{ Incubation time in the rumen(hrs) } \\
\hline & 0 & 2 & 4 & 8 & 12 & 24 & 48 \\
\hline & & & & $\%$ & & & \\
\hline Whole corn L & $8.78^{\mathrm{a}}$ & $9.09^{\mathrm{c}}$ & $8.97^{\mathrm{d}}$ & $9.06^{\mathrm{e}}$ & $9.45^{\mathrm{e}}$ & $8.87^{\mathrm{e}}$ & $8.84^{\mathrm{e}}$ \\
\hline Whole corn $\mathrm{H}$ & $8.65^{\mathrm{b}}$ & $8.70^{\mathrm{d}}$ & $9.14^{\mathrm{c}}$ & $9.07^{\mathrm{e}}$ & $8.37^{\mathrm{f}}$ & $8.56^{\mathrm{f}}$ & $8.24^{\mathrm{f}}$ \\
\hline Ground corn & $8.37^{\mathrm{d}}$ & $9.24^{\mathrm{b}}$ & $9.25^{\mathrm{c}}$ & $10.16^{\mathrm{c}}$ & $10.26^{\mathrm{c}}$ & $13.32^{\mathrm{c}}$ & $13.39^{\mathrm{d}}$ \\
\hline Flaked, $3.8 \mathrm{~mm}$ & $8.58^{\mathrm{c}}$ & $8.71^{\mathrm{d}}$ & $8.76^{\mathrm{e}}$ & $9.68^{\mathrm{d}}$ & $9.97^{\mathrm{d}}$ & $11.61^{\mathrm{d}}$ & $14.33^{\mathrm{c}}$ \\
\hline Flaked, $2.8 \mathrm{~mm}$ & $8.58^{\mathrm{c}}$ & $9.22^{\mathrm{b}}$ & $9.47^{\mathrm{b}}$ & $10.37^{\mathrm{b}}$ & $11.26^{\mathrm{b}}$ & $14.27^{\mathrm{b}}$ & $22.13^{\mathrm{b}}$ \\
\hline Flaked, $1.5 \mathrm{~mm}$ & $7.66^{\mathrm{e}}$ & $10.70^{\mathrm{a}}$ & $10.70^{\mathrm{a}}$ & $13.71^{\mathrm{a}}$ & $16.04^{\mathrm{a}}$ & $25.18^{\mathrm{a}}$ & $32.12^{\mathrm{a}}$ \\
\hline SEM & 0.086 & 0.163 & 0.153 & 0.384 & 0.597 & 1.352 & 2.022 \\
\hline
\end{tabular}

a,b,c,d,e,f Means in the same column with different superscripts are significantly $\operatorname{different}(\mathrm{P}<0.05)$.

(3) 단백질 분해상수

Table 9는 분해도 공식(Ørskov와 McDonald, 1979)으로 산출한 a, b, c 값이다. "a"값을 보면 분쇄 옥수수가 $17.9 \%$ 로 가장 높았고, 다음이 통 옥수수 L 및 $\mathrm{H}(13.1$ 및 $12.3 \%$ )이었으며, 3.8 $\mathrm{mm}$ 및 $2.8 \mathrm{~mm}$ flake(5.2 및 $4.7 \%$ )는 가장 낮았 다 $(\mathrm{P}<0.05)$. 이는 flake 가공처리시에 습열 가압 하면 미세 입자의 양이 줄어들기 때문으로 생 각된다. 반추위 내에서의 분해율에 결정적인
영향을 미치는 매우 중요한 상수인 “c”값(반추 위 내에서 미생물에 의해 분해되는 값인 ' $b$ '부 분이 시간당 반추위를 통과하는 속도)은 flake 처리시와 분쇄시에 $0.043 \sim 0.055$ 범위로서 비슷 한 경향이었다. 통 옥수수의 경우에는 $\mathrm{L}$ 및 $\mathrm{H}$ 가 각각 0.022 및 0.016 으로 가공처리시와 비교 하여 유의하게 낮아졌으며, density가 낮은 통 옥수수(0.022)가 높은 것(0.016)보다 반추위내에 서 $35 \%$ 가량 빠른 통과속도를 나타내었으나

Table 9. Protein degradation parameters of untreated and treated corns by incubation time in the rumen

\begin{tabular}{lccc}
\hline \multirow{2}{*}{ Treatments } & \multicolumn{3}{c}{ Degradation parameters } \\
\cline { 2 - 4 } & $\mathrm{a}(\%)$ & $\mathrm{b}(\%)$ & $\mathrm{c}$ \\
\hline \hline Whole corn L & $13.1^{\mathrm{b}}$ & $31.2^{\mathrm{b}}$ & $0.022^{\mathrm{bc}}$ \\
Whole corn H & $12.3^{\mathrm{b}}$ & $24.7^{\mathrm{b}}$ & $0.016^{\mathrm{c}}$ \\
Ground corn & $17.9^{\mathrm{a}}$ & $57.3^{\mathrm{a}}$ & $0.043^{\mathrm{ab}}$ \\
Flaked, $3.8 \mathrm{~mm}$ & $5.2^{\mathrm{d}}$ & $30.7^{\mathrm{b}}$ & $0.055^{\mathrm{a}}$ \\
Flaked, $2.8 \mathrm{~mm}$ & $4.2^{\mathrm{d}}$ & $46.5^{\mathrm{a}}$ & $0.043^{\mathrm{ab}}$ \\
Flaked, $1.5 \mathrm{~mm}$ & $7.9^{\mathrm{c}}$ & $53.6^{\mathrm{a}}$ & $0.045^{\mathrm{a}}$ \\
\hline SEM & 1.13 & 3.28 & 0.0041 \\
\hline
\end{tabular}

$\overline{\text { a,b,c,d }}$ Means in the same column with different superscripts are significantly $\operatorname{different}(\mathrm{P}<0.05)$. 
Table 10. Effective protein degradabilities of untreated and treated corns by incubation time in the rumen

\begin{tabular}{lccc}
\hline \multirow{2}{*}{ Treatments } & \multicolumn{2}{c}{ ERD*(\%) } \\
\cline { 2 - 4 } & $\mathrm{k}=0.02$ & $\mathrm{k}=0.04$ & $\mathrm{k}=0.06$ \\
\hline \hline Whole corn L & $22.7^{\mathrm{bc}}$ & $19.7^{\mathrm{d}}$ & $18.1^{\mathrm{d}}$ \\
Whole corn H & $18.5^{\mathrm{c}}$ & $16.5^{\mathrm{d}}$ & $15.6^{\mathrm{d}}$ \\
Ground corn & $44.8^{\mathrm{a}}$ & $38.4^{\mathrm{a}}$ & $34.4^{\mathrm{a}}$ \\
Flaked, $3.8 \mathrm{~mm}$ & $22.5^{\mathrm{c}}$ & $18.3^{\mathrm{d}}$ & $15.8^{\mathrm{d}}$ \\
Flaked, $2.8 \mathrm{~mm}$ & $33.5^{\mathrm{b}}$ & $26.7^{\mathrm{c}}$ & $22.6^{\mathrm{c}}$ \\
Flaked, $1.5 \mathrm{~mm}$ & $39.6^{\mathrm{ab}}$ & $32.2^{\mathrm{b}}$ & $27.6^{\mathrm{b}}$ \\
\hline SEM & 1.73 & 2.01 & 2.50 \\
\hline
\end{tabular}

ERD*: Effective rumen degradability calculated with the equation of $E R D=a+b[c /(c+k)]$, where $k$ is the rate of passage set at $0.02,0.04$ and 0.06 .

a,b,c,d Means in the same column with different superscripts are significantly different $(\mathrm{P}<0.05)$.

유의적인 차이는 없었다 $(\mathrm{P}<0.05)$.

\section{(4) 유효 단백질 분해도}

반추위 내에서의 시간당 통과속도 $\mathrm{k}=0.02$, $0.04,0.06$ 를 적용한 유효 단백질 분해도는 Table 10 에서 보는 바와 같다. Table 8 에서의 단백질 분해상수와 연관지어 고찰할 때, 반추 위내의 유효 단백질 분해도는 density가 낮은 통 옥수수 L은 $22 \%$, density가 높은 통 옥수수 $\mathrm{H}$ 는 $19 \%$, 분쇄 옥수수는 $38 \%, 1.5 \mathrm{~mm}$ flake는 $32 \%, 2.8 \mathrm{~mm}$ 는 $26 \%, 3.8 \mathrm{~mm}$ 는 $15 \%$ 정도로 추 산할 수 있었다. 각각의 통과속도를 적용시에 $(\mathrm{k}=0.02, \mathrm{k}=0.04, \mathrm{k}=0.06)$ flake 처리를 하면 분 쇄시보다 반추위 내에서의 유효 단백질 분해도 가 유의하게 낮아졌는데 $(\mathrm{P}<0.05)$, 이는 Fiems 등(1990)과 Focant 등(1990)의 보고에서와 같이 flake 처리시에는 젤라틴화된 전분이 반추위 내 에서의 단백질 분해율을 감소시켜, 하부장기내 의 단백질 유입량, 즉, by pass protein의 양이 늘어났기 때문으로 생각된다. Flake 가공방법들 간에는 두께가 얇을수록 유효단백질의 분해도 가 높아지는 경향을 나태내었는데 이는 가공정 도에 따른 젤라틴화의 증가로 인한 단백질 분
해율의 감소치보다 density의 감소에 따른 표적 적의 증가로 인한 분해율이 증가되었기 때문으 로 사료된다.

사료 원료의 물리적 특성은 반추위내 배양시 간별 영양소 이용율에 양향을 미치므로 분해특 성을 적절히 고려하면 단백질원과 탄수화물원 의 반추위내 발효 동기화를 보다 최적화할 수 있을 것이다.

$$
\text { IV. 요 약 }
$$

옥수수 알곡의 무처리(통 옥수수 2종) 및 가 공방법(분쇄, flake $3.8 \mathrm{~mm}, 2.8 \mathrm{~mm}$ 및 $1.5 \mathrm{~mm}$ )이 in sacco 방법에 있어 반추위 내에서의 전분 및 단백질 분해율에 미치는 영향을 측정하고자 반 추위에 캐뉼라(cannulae)가 장착된 홀스타인종 건유우 3 두를 공시축으로 하여, 본 시험을 수 행하였는데 그 결과를 요약하면 다음과 같다.

1) 48 시간대에서의 전분 분해율은 $1.5 \mathrm{~mm}$, $2.8 \mathrm{~mm}$ flake, 분쇄 옥수수, $3.8 \mathrm{~mm}$ flake, density $660 \mathrm{~g} / \ell$, density $740 \mathrm{~g} / \ell$ 인 통 옥수수 순으로 높았다. Flake의 가공정도를 증진시키면, 즉 $3.8 \mathrm{~mm}$ 에서 $2.8 \mathrm{~mm}$ 로 얇게 가공하면 전분 분해 
율이 유의하게 증가되었으며, $1.5 \mathrm{~mm}$ 로 더욱 얇 게 가공하면 $2.8 \mathrm{~mm}$ 보다 증가하는 경향을 보 였으나 유의적인 차이는 없었다 $(\mathrm{P}<0.05) .12$ 시 간대에서 24시간대까지는 density가 낮은 통 옥 수수가 높은 것보다 많이 분해되는 경향을 보 였으나, 유의적인 차이가 없었고, 48 시간대에서 는 유의하게 높았다 $(\mathrm{P}<0.05)$.

2) 단백질 분해율은 반추위내 배양시간이 경 과함에 따라 모두 증가하는 경향이었다. 48시 간대에서의 단백질 분해율은 분쇄 옥수수, 1.5 $\mathrm{mm}, 2.8 \mathrm{~mm}, 3.8 \mathrm{~mm}$ flake의 순으로 높았다 $(\mathrm{P}<0.05)$. Flaking 처리시의 단백질 분해율은 분 쇄 옥수수보다 유의하게 낮아졌으나, 8 48시 간대에서는 $2.8 \mathrm{~mm}, 1.5 \mathrm{~mm}$ 로 가공정도를 증진 시킬수록 높아지는 경향이었다.

3) "a"값, 즉 물에 녹는 수용성 부분을 계산 한 결과, 단백질의 "a"값은 flake가 분쇄 옥수 수보다 유의하게 낮았다. 반면에 전분의 "a"값 은 flake가 분쇄 옥수수보다 높았다. 곡류를 flaking 처리하면 전분이 젤라틴화 되어, 반추 위 내에서 전분 분해속도는 증가되고, 단백질 분해속도는 감소되기 때문이라고 생각된다.

이와 같이 사료원료의 물리적 특성은 반추위 내 배양시간별 영양소 이용율에 양향을 미친 다. 그러므로, 반추가축 사료에 이용되는 원료 들의 이와 같은 분해특성을 적절히 고려하면 단백질원과 탄수화물원의 반추위내 발효 동기 화를 보다 최적화할 수 있을 것이다.

\section{$\mathrm{V}$. 인 용 문 헌}

1. Alio, A., Theurer, C. B., Lozano, O., Huber, J. T., Swingle, R. S., Delgado-Elorduy, A., Cuneo, P., DeYoung, D. and Webb, Jr. K. E. 2000. Splanchnic nitrogen metabolism by growing beef steers fed diets containing sorghum grains flaked at different densities. J. Anim. Sci. 78:1355.

2. AOAC. 1990. Official methods of analytical chemists., Washington, D.C., U.S.A.

3. Brown, M. S., Krehbiel, C. R., Galyean, M. L., Remmenga, M. D., Peters, J. P., Hibbard, B.,
Robinson, J. and Moseley, W. M. 2000a. Evaluation of models of acute and subacute acidosis on dry matter intake, ruminal fermentation, blood chemistry, and endocrine profiles of beef steers. J. Anim. Sci. 78:3155.

4. Brown, M. S., Krehbiel, C. R., Duff, G. C., Galyean, M. L., Hallford, D. M. and Walker, D. A. 2000b. Effect of degree of corn processing on urinary nitrogen composition, serum metabolite and insulin profiles, and performance by finishing steers. J. Anim. Sci. 78:2464.

5. Callison, S. L., Firkins, J. L., Eastridge, M. L. and Hull, B. L. 2001. Site of nutrient digestion by dairy cows fed corn of different particle sizes or steam-rolled. J. Dairy Sci. 84:1458.

6. Duncan, D. B. 1955. Multiple range and multiple F tests. Biometrics. 11:1.

7. Fiems, L. O., Cottyn, B. G., Ch. Boucque, V., Vanacker, J. M. and Buysse, F. X. 1990. Effect of grain processing on in sacco digestibility and degradability in the rumen. Arch. Anim. Nutri. 40:713.

8. Focant, M. A., Van Hoecke and Vanbelle, M. 1990. Influence of steam flaking wheat on rumen fermentations and duodenal nitrogen and amino acids flows in heifers. Anim. Feed Sci. Tech. 30:69.

9. Fredrick, H. M., Threurer, B. and Hale, W. H. 1973. Effect of moisture, pressure and temperature on enzymatic starch degradation of barley and sorghum grains. J. Dairy Sci. 56:595.

10. Lozano, O., Theurer, C. B., Alio, A., Huber, J. T., Delgado-Elorduy, A., Cuno, P., DeYoung, D., Sadik, M. and Swingle, R. S. 2000. Net absorption and hepartic metabolism of glucose, $l$-lactate, and volatile fatty acids by steers fed diets containing sorghum grains processed as dry-rolled or steam-flaked at different densities. J. Anim. Sci. 78:1364.

11. Marquadt, W. 1963. An algorithm for least squares estimation of nonlinear parameters. Soc. Ind. Appl. Math. 11:431.

12. NRC. 1984. Ruminant nitrogen usage(6th Ed.). National Academy Press, Washington, D.C., USA.

13. NRC. 2001. Protein and $\operatorname{amino} \operatorname{acids}(7 t h$ Ed.). National Academy Press, Washington, D.C., USA. 
14. Ørskov, E. R. and MacDonald, I. 1979. The estimation of protein degradability in the rumen from incubation measurements weighted according to rate of passage. J. Agri. Camb. 92:499.

15. Owens, F. N., Zinn, R. A. and Kim, Y. K. 1986. Limits to starch digestion in the ruminant small intestine. J. Animi. Sci. 63:1634.

16. Philippeau, C., Le Deschault de Monredon, F. and Michalet-Doreau, B. 1999. Relationship between ruminal starch degradation and the physical characteristics of corn grains. J. Anim. Sci. 77: 238.

17. SAS. 1988. User's Guide: Statistics. SAS Inst. Inc., Carry, NC, USA.

18. Sniffen, C. J., O'Connor, J. D., Van Soest, P. J., Fox, D. G. and Russell, J. B. 1992. A net carbohydrate and protein system for evaluating cattle diets: $\Pi$. Carbohydrate and protein availability. J. Anim. Sci. 70:3562.

19. Theurer, C. B., Lozano, O., Alio, A., DelgadoElorduy, A., Sadik, M., Huber, J. T. and Zinn, R. A. 1999. Steam-processed corn and sorghum grain flaked at different densities alter ruminal, small intestinal, and total tract digestibility of starch by steers. J. Anim. Sci. 77:2824.

20. Van Keuren, R. W. and Heineman, W. W. 1662. Study of a nylon bag technique for in vivo estimation of forage digestibility. J. Anim. Sci. 21:340.

21. Volden, H. 1999. Effects of level of feeding and ruminally undegraded protein on ruminal bacterial protein synthesis, escape of dietary protein, intestinal amino acid profile, and performance of dairy cows. J. Anim. Sci. 77:1905.

22. Xiong, Y., Bartle, S. J. and Preston, R. L. 1991. Density of steam-flaked sorghum grains, roughage level and feeding regimen for feedlot steers. J. Anim. Sci. 69:1707.

23. Zinn, R. A. 1990a. Influence of flake density on the comparative feeding value of steam-flaked corn for feedlot cattle. J. Anim. Sci. 68:767.

24. Zinn, R. A. 1990b. Influence of steaming time on the site of digestion of flaked corn in steers. J. Anim. Sci. 68:776.

25. 한국축산연감. 2002. 농수축산신문.

(접수일자 : 2003. 1. 16 / 채택일자 : 2003. 4. 14) 